Vol. 5 No.1 Januari 2022

http://jurnal.umsb.ac.id/index.php/RANGTEKNIKJOURNAL

\title{
Pengembangan Aplikasi Si-Book Untuk Monitoring Dan Evaluasi Kinerja Pegawai Pada Modul Evaluation Dengan Metode Iterative Incremental
}

\author{
Muhammad Zikri ${ }^{1}$, Rahmat Fauzi ${ }^{2}$, Ekky Novriza Alam ${ }^{3}$ \\ Fakultas Rekayasa Industri, Telkom University ${ }^{1,2,3}$ \\ Email: zikrim@student.telkomuniversity.ac.id ${ }^{1}$,rahmatfauzi@ telkomuniversity.ac.id ${ }^{2}$, \\ ekkynovrizaalam@telkomuniversity.ac.id ${ }^{3}$ \\ DOI: http://dx.doi.org/10.31869/rtj.v5i1.2903
}

\begin{abstract}
The research being conducted is currently at the Regional Tax and Retribution Management Agency (BPPRD) of Jambi City. Problems that occur in Jambi City (BPPRD) are that the tasks given to employees are still carried out through verbal communication, employees have difficulty getting assessments and evaluations from superiors, and there are no tools used to measure employee performance. Therefore, it is necessary to develop a web-based application with the name SI-BOOK to monitor and evaluate employee performance in the hope of solving the problems encountered. To be able to solve this problem there is an agile approach that uses the iterative incremental method.
\end{abstract}

Keywords: Monitoring and Evaluation, Evaluation Module, Iterative Incremental, Black box testing, SI-BOOK

Abstrak: Penelitian yang dilakukan saat ini berada di Badan Pengelola Pajak dan Retribusi Daerah (BPPRD) Kota Jambi. Permasalahan yang terjadi di (BPPRD) Kota Jambi adalah tugas yang diberikan kepada pegawai masih dilakukan melalui komunikasi verbal, pegawai kesulitan mendapatkan penilaian dan evaluasi dari atasan, dan tidak adanya tools yang digunakan untuk mengukur kinerja pegawai. Oleh karena itu perlu dikembangkan sebuah aplikasi berbasis website dengan nama SI-BOOK untuk Monitoring dan evaluasi kinerja pegawai dengan harapan dapat memecahkan permasalahan yang sedang dihadapi. Untuk bisa menyelesaikan permasalahan terdapat pendekatan yang digunakan yaitu agile dengan menggunakan metode iterative incremental.

Kata Kunci : Monitoring dan Evaluasi, Modul Evaluation, Iterative Incremental, Black-box testing, SI-BOOK.

\section{PENDAHULUAN}

Perkembangan teknologi pada dunia global saat ini tidak dapat terpisahkan dalam kehidupan sehari-hari. Hampir setiap kantor, industri, akademik, pemerintahan, bahkan masyarakat memakai perangkat komputer untuk berbagai keperluan. Kemajuan teknologi yang semakin pesat tidak terlepas dari campur tangan manusia dalam melakukan hal yang baru. Salah satu organisasi yang mengikuti perkembangan teknologi informasi adalah Badan Pengelola Pajak dan Retribusi Daerah (BPPRD) Kota Jambi. Salah satu tujuan yang ingin dicapai adalah mendukung kinerja pegawai untuk monitoring dan evaluasi pencapaian pegawai yang sudah dilakukan

Badan Pengelola Pajak dan Retribusi Daerah (BPPRD) Kota Jambi saat ini sudah ada aplikasi E-Kinerja yang sudah digunakan untuk mengukur kinerja masing-masing pegawai sesuai bidang pekerjaan dan kriteria yang didapatkan untuk mewujudkan keberhasilan misi dan visi perusahaan. IPK individu diisi setiap sekali sebulan oleh masing-masing pegawai dan akan divalidasi oleh atasan sebagai tanda bahwa kinerja tersebut sudah tercapai dan ditulis pada form tersebut. Setiap pengisian yang dilakukan oleh pegawai mengalami permasalahan IPK individu diantaranya tugas yang diberikan kepada pegawai masih dilakukan melalui komunikasi verbal, pegawai kesulitan mendapatkan penilaian dan evaluasi dari atasan, dan tidak adanya tools yang digunakan untuk mengukur kinerja pegawai. permasalahan tersebut kerap kali mengalami kendala dalam pengisian IPK terutama yang berada pada unit kerja non operasional mayoritas lebih mengarah ke target penyelesaian pekerjaan yang ditetapkan dan unit operasional di dominasi dengan penyelesaian pekerjaan secara angka.

Oleh karena itu perlu dikembangkan sebuah aplikasi berbasis website dengan nama 
SI-BOOK (System Information Electronic Logbook) untuk Monitoring dan evaluasi kinerja pegawai dengan harapan dapat memecahkan permasalahan yang sedang dihadapi. Aplikasi SI-BOOK atau System Information Electronik Logbook merupakan aplikasi yang digunakan untuk memberikan tugas secara online sehingga pekerjaan tersebut mudah untuk dikumpulkan dan memberikan penilaian terhadap kinerja pegawai yang akan dijadikan sebagai tolak ukur dalam melakukan pekerjaan.

Menurut Khalid Nabris (2002) dalam Mustofa (2012) "Monitoring merupakan aktivitas secara terus menerus untuk melacak kemajuan pelaksanaan program apakah sudah sesuai dengan perencanaan". Menurut Arisantoso (2014) dalam Susanto (2020) "Monitoring merupakan kegiatan yang dilakukan untuk mengetahui apakah program tersebut sudah berjalan dengan baik sesuai yang direncanakan, dan ada kendala serta bagaimana bisa mengatasi pelaksanaan saat dalam mengalami kendala". Jadi dapat diambil kesimpulan bahwa monitoring merupakan kegiatan yang dilakukan untuk mengetahui aktivitas yang sedang berlangsung apakah sudah sesuai dengan program atau bukan.

Menurut Suharsimi, Jabar, dan Sarifudin (2008) dalam Ariefni, dan Legowo (2018) "Evaluasi adalah kegiatan untuk mengumpulkan informasi tentang bekerjanya sesuatu, yang selanjutnya informasi tersebut digunakan untuk menentukan alternatif yang tepat dalam mengambil sebuah keputusan". Menurut Hamdala, dan Esabella (2020) "Evaluasi adalah penilaian berkala terhadap relevansi, penilaian, efisiensi, dan dampak proyek tentang waktu, daerah atau populasi”. Jadi dapat diambil kesimpulan bahwa evaluasi merupakan kegiatan yang digunakan untuk mengumpulkan informasi berdasarkan penilaian, relevansi, efisiensi dan dampak yang akan dijadikan sebagai pengambilan keputusan.

Untuk menyelesaikan permasalahan tersebut terdapat pendekatan yang bisa digunakan, salah satunya adalah pendekatan Agile. Pendekatan Agile merupakan pendekatan yang iterative dan evolusioner dengan mengedepankan kolaborasi serta menggunakan dokumen formal yang terbatas dan membangun perangkat lunak yang berkualitas tepat serta efisiensi biaya sesuai dengan kebutuhan stakeholder yang bisa berubah-ubah. Prinsip-prinsip pendekatan Agile yaitu : fokus pada kolaborasi, working software, didasarkan pengalaman dan penerapan (Raharjana, 2017).

Dalam pendekatan Agile, terdapat metode untuk menyelesaikan permasalahan yang terjadi, salah satunya adalah metode Iterative Incremental. Metode Iterative Incremental adalah metode pengembangan perangkat lunak yang bentuk modelnya dibuat secara bertahap dan berulang-ulang. Pengertian Iterative incremental terdiri dari dua kata yaitu : Iterative dan Incremental. Iterative merupakan tahap yang digunakan untuk rencana penjadwalan pembangunan sistem yang akan dikembangkan dalam waktu dan tingkatan yang berbeda. Sedangkan incremental merupakan rencana perulangan dalam mengembangkan sistem untuk melakukan revisi dari pengembangan sistem (Rahmadi, Adam, dan Azani, 2015). Siklus dalam pengembangan sistem menggunakan iterative incremental terdiri dari 4 tahapan utama yaitu : Planning (Perencanaan), Design (Perancangan), Development (Pengkodingan), dan Testing (Pengujian). Setelah melakukan tahapan utama tersebut maka dilanjutkan ke tahap yang lain yaitu Feedback (Masukan), Deployment (Hosting) (Moniruzzaman \& Hossain, 2013). Kelebihan menggunakan metode iterative incremental adalah dapat beradaptasi dengan perubahan jika pengembangan sistem tersebut sedang dilaksanakan, cocok digunakan untuk pengembangan sistem dalam skala besar, mudah untuk menemukan kesalahan, sistem yang dihasilkan dapat bekerja dengan baik (Hemera Academy, 2020).

Pada penelitan yang berjudul "Analisa dan Perancangan Aplikasi Manajemen Kinerja CV. Media Kreatif Online" oleh Eka Oktaviani, Hendi Setiawan, dan Kevin Perdana pada tahun 2019. Menujukkan bahwa hasil penelitian tersebut adalah bahwa metode iterative incremental dapat digunakan untuk pengembangan aplikasi dan pengguna dapat melihat hasil produk yang sudah selesai dibuat serta dapat memberikan feedback atau masukan selama dalam pengembangan aplikasi tersebut. Maka dari itu metode ini dapat diterapkan untuk membangun aplikasi SI-BOOK untuk Monitoring dan evaluasi 
kinerja pegawai Badan Pengelola Pajak dan Retribusi Daerah (BPPRD) Kota Jambi.

\section{METODE PENELITIAN}

Proses penelitian ini akan dijelaskan mengenai teknik pengumpulan data, dan metode pengembangan sistem.

1. Teknik pengumpulan data yang digunakan dalam penelitian ini yaitu:

a. Observasi

Observasi atau pengumpulan data dilakukan dengan cara metode kualitatif. Metode kualitatif adalah metode yang dilakukan dengan cara pengolahan data menggunakan tertulis di lingkungan yang sedang diamati di BPPRD Kota Jambi.

b. Wawancara

Wawancara dilakukan kepada Kepala Subbidang Pembukuan dan Pelaporan dan Staf Pembukuan dan Pelaporan yang ada di BPPRD Kota Jambi yang akan dirancang dalam penelitian ini.

2. Model Pendekatan Penelitian

Model Pendekatan Penelitian ini dilakukan dengan cara mengembangkan aplikasi SI-BOOK di BPPRD Kota Jambi

a. Model Pengembangan Perangkat Lunak

Metode yang digunakan pada penelitian ini adalah metode Iterative Incremental yang merupakan turunan dari metode SDLC (System Development Life Cycle). Metode iterative adalah metode yang berfokus untuk kemajuan dan penyempurnaan aplikasi sehingga menghasilkan rincian yang bagus, sedangkan metode incremental adalah metode yang berfokus terhadap rencana untuk mengembangkan aplikasi yang sedang dikerjakan dari tahap satu ke tahap berikutnya sampai waktu yang sudah ditentukan (Rahmadi \& H, 2015). Adapun tahapan-tahapan metode iterative incemental yaitu (Moniruzzaman \& Hossain, 2013):

1) Tahap Planning (Perencanaan)

Pada tahap planning ini peneliti melakukan analisis dan pengumpulan kebutuhan atau requirement terhadap aplikasi yang akan dikembangkan sesuai dengan pengelompokkan berdasarkan permasalahan yang sedang dialami terutama pada modul evaluation.

2) Tahap Design (Desain)

Pada tahapan design ini dilakukan dengan mengimplementasikan hasil permasalahan dalam bentuk user interface (UI), pemodelan sistem menggunakan UML (Unified Modeling Language) dan desain database yang akan dilakukan.

3) Tahap Development (Pengkodean)

Pada tahapan development peneliti menerapkan user interface (UI) dengan menggunakan bahasa pemrograman. Bahasa yang digunakan adalah PHP, database yang digunakan menggunakan MySQL.

4) Tahap Testing (Pengujian)

Pada tahapan testing ini dilakukan dengan cara pengujian sistem yang akan digunakan untuk mengetahui kesalahan apa saja yang muncul saat aplikasi tersebut sedang berjalan serta mengetahui apakah sudah sesuai dengan kebutuhan pengguna atau belum.

5) Tahap Evaluation (Evaluasi)

Pada tahapan evaluation ini dilakukan menggunakan feedback terhadap penelitian dalam pengembangan aplikasi dengan harapan dapat memberikan solusi yang tepat dan referensi pengembangan aplikasi dimasa yang akan datang.

6) Tahap Deployment (Implementasi)

Pada tahapan deployment ini dilakukan dengan cara mengimplementasikan hasil pemgembangan aplikasi yang sudah dikerjakan.

b. Pengujian dan Evaluasi Sistem

Pada tahapan ini dilakukan pengujian aplikasi yang sudah selesai dibuat. Pengujian tersebut menggunakan black-box testing yang berfokus kepada fungsionalitas atau kegunaan sebuah aplikasi untuk mengetahui apakah setiap input maupun hasil output tidak mengalami kegagalan sistem/error (Jovanovic \& Irena, 2009). 


\section{HASIL DAN PEMBAHASAN}

Di dalam use case diagram terdapat tiga aktor yang dirancang yaitu : Pihak Admin, Pihak Manajemen, dan Pihak Pegawai dengan fungsionalitas sistem yang ada pada use case diagram aplikasi SI-BOOK Modul Evaluation yang digambarkan pada Gambar 1. Pada Gambar 1 merupakan use case diagram dimana pihak manajemen manambahkan evaluation yang berfungsi untuk melakukan penilaian pekerjaan pegawai. Pihak admin dapat mengubah kategori indikator, mengubah indikator penilaian, serta dapat melihat feedback dan penilaian pegawai. kemudian untuk pihak pegawai dapat melihat feedback dan penilaian yang sudah diberikan.

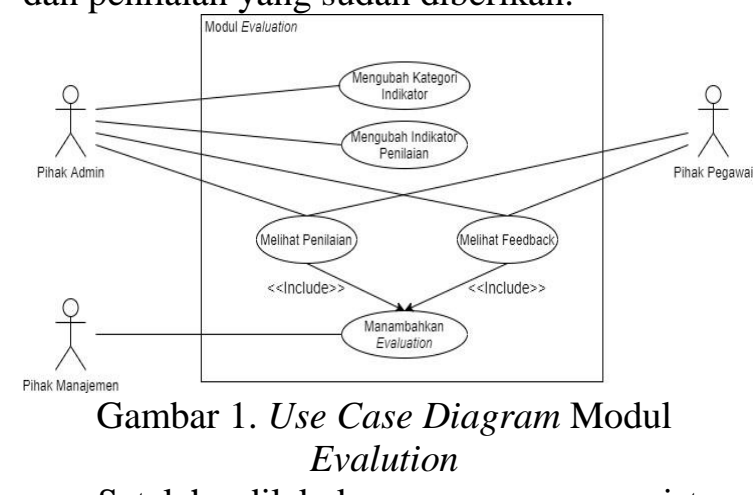

Setelah dilakukan perancangan sistem selanjutkan dilakukan dengan cara mengimplementasikan dengan menggunakan metode iterative incremental. Pada setiap iterasi fase pertama pengembangan aplikasi SI-BOOK Modul Evaluation pada BPPRD Kota Jambi berbasis website menggunakan framework codeigniter, dan bootsrap yang dapat mempermudah dalam membuat, menyimpan, membaca, mengedit dan menghapus. Uraian tersebut akan dijabarkan sebagai berikut:

1. Halaman Input Evaluasi

Halaman input evaluasi pada Modul evaluation merupakan halaman yang digunakan untuk menilai kinerja pegawai berdasarkan tugas yang diberikan oleh atasan dan disimpan didalam database. Pihak atasan terlebih dahulu mengisi form dimana ada beberapa atribut yang harus diisi yaitu: jenis pekerjaan, rentang tanggal pengerjaan logbook, dan nama pegawai. Bentuk form input evaluasi yang dapat dilihat pada Gambar 2.

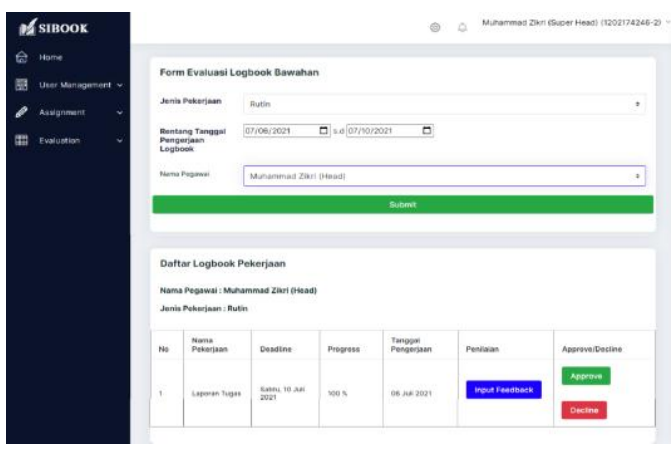

Gambar 2. Halaman Input Evaluasi

2. Halaman View Feedback

Halaman View Feedback pada Modul evaluation merupakan halaman yang digunakan untuk melihat feedback yang sudah diberikan oleh atasan dan disimpan didalam database. Untuk bisa melihat feedback, pihak atasan terlebih dahulu mengisi form dimana ada beberapa atribut yang harus diisi, yaitu: memilih jenis tugas, memilih rentang tanggal pengerjaan

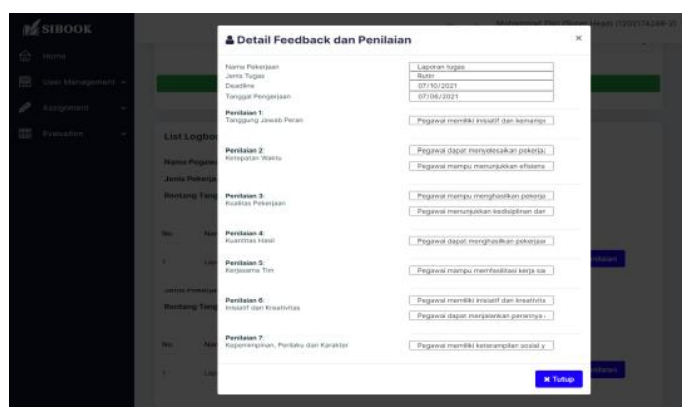

logbook. Bentuk view feedback yang dapat dilihat pada Gambar 3 .

Gambar 3. Halaman Detail Feedback

3. Halaman View Tabel Penilaian

Halaman view tabel penilaian pada Modul Evaluation merupakan halaman yang digunakan untuk melihat jumlah total penilaian yang sudah diberikan oleh atasan berdasarkan tugas dan disimpan didalam database. Untuk bisa melihat tabel penilaian, pihak atasan terlebih dahulu mengisi form dimana ada beberapa atribut yang harus diisi yaitu: memilih jenis tugas, memilih rentang tanggal waktu pengerjaan, dan lihat logbook. Bentuk view tabel penilaian yang dapat dilihat pada Gambar 4. 

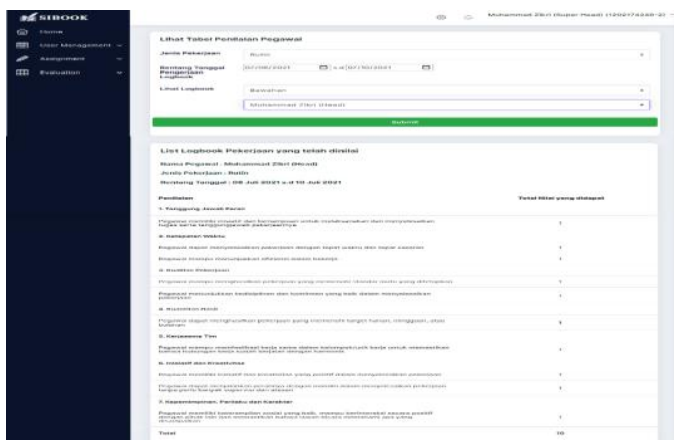

Gambar 4. Halaman View Penilaian

Pengujian ini dilakukan untuk mengetahui apakah kebutuhan tersebut sudah sesuai atau belum. Hal tersebut dapat dilihat seiring berjalannya aplikasi SI-BOOK untuk mengetahui keseluruhan fungsional yang terdapat pada Modul Evaluation. Pengujian dan hasil yang diperoleh dilakukan menggunakan black-box testing pada aplikasi SI-BOOK dengan menggunakan metode Iterative Incremental yang dapat dilihat pada Tabel 1.

Tabel 1. Hasil Pengujian Menggunakan BlackBox Testing Iterasi Fase Pertama

\begin{tabular}{|c|c|c|c|}
\hline No. & $\begin{array}{l}\text { Fitur Yang } \\
\text { Diujikan }\end{array}$ & $\begin{array}{l}\text { Hasil Yang } \\
\text { Diharapkan }\end{array}$ & Kesesuaian \\
\hline 1. & $\begin{array}{l}\text { Input } \\
\text { Evaluasi }\end{array}$ & $\begin{array}{l}\text { Pihak } \\
\text { Manajemen } \\
\text { sebagai } \\
\text { pengguna } \\
\text { dapat } \\
\text { mengisi } \\
\text { input } \\
\text { evaluasi } \\
\text { pegawai }\end{array}$ & $100 \%$ \\
\hline 2. & $\begin{array}{l}\text { View } \\
\text { Feedback }\end{array}$ & $\begin{array}{l}\text { Pihak } \\
\text { Manajemen } \\
\text { sebagai } \\
\text { pengguna } \\
\text { dapat } \\
\text { melihat } \\
\text { feedback }\end{array}$ & $100 \%$ \\
\hline 3. & $\begin{array}{l}\text { View Tabel } \\
\text { Penilaian }\end{array}$ & $\begin{array}{l}\text { Pihak } \\
\text { Manajemen } \\
\text { sebagai } \\
\text { pengguna } \\
\text { dapat } \\
\text { melihat } \\
\text { tabel } \\
\text { penilaian } \\
\text { yang sudah } \\
\text { diisi }\end{array}$ & $100 \%$ \\
\hline
\end{tabular}

Setelah dilakukan pengujian menggunakan black-box testing pada iterasi fase pertama, mendapatkan feedback atau masukan untuk dapat meningkatkan kualitas dari aplikasi SIBOOK Modul Evaluation. Adapun poin-poin feedback yang diberikan oleh pengguna aplikasi SI-BOOK Modul Evaluation yaitu :

1. Diperlukan fitur setting kategori indikator pada role admin untuk dapat mengubah kategori-kategori penilaian pegawai yang akan dilakukan kedepannya.

2. Diperlukan fitur setting indikator penilaian pada role admin untuk dapat mengubah penilaian-penilaian pegawai yang akan dilakukan kedepannya.

Selanjutnya pada fase iterasi kedua dilakukan dengan cara menambahkan fitur pada pengembangan aplikasi SI-BOOK Modul Evaluation setelah dilakukan feedback dari fase iterasi pertama pada metode iterative incremental. Pada gambar 5 dan gambar 6 menunjukkan hasil implementasi aplikasi SIBOOK Modul Evaluation pada fase iterasi kedua. Uraian tersebut akan dijabarkan sebagai berikut:

4. Halaman Setting Kategori Indikator Halaman setting kategori indikator merupakan halaman yang digunakan untuk mengatur kategori indikator yang dilakukan oleh pihak admin. Bentuk setting kategori indikator dapat dilihat pada Gambar 5.

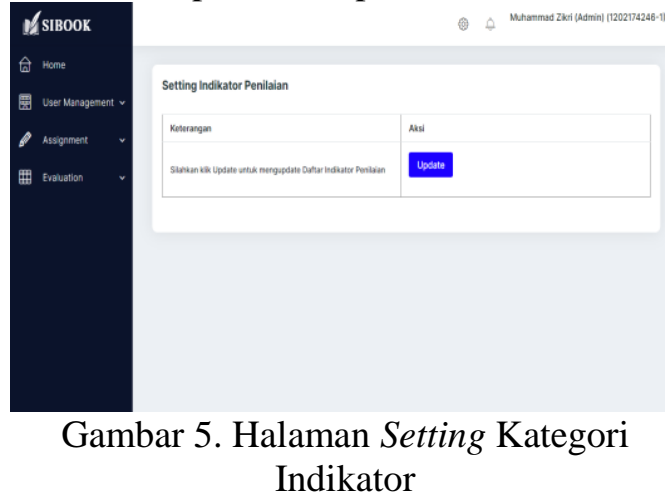

5. Halaman Setting Indikator Penilaian

Halaman setting indikator penilaian merupakan halaman yang digunakan untuk mengatur indikator penilaian yang dilakukan oleh pihak admin. Bentuk setting indikator penilaian dapat dilihat pada Gambar 6. 


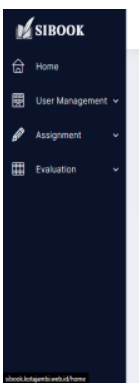

Gambar 6. Halaman Setting Indikator Penilaian

Pengujian yang dilakukan menggunakan black-box testing pada iterasi fase kedua dengan metode iterative incremenal aplikasi SI-BOOK Modul Evaluation dapat dilihat pada tabel 2.

Tabel 2. Hasil Pengujian Menggunakan BlackBox Testing Iterasi Fase Kedua

\begin{tabular}{|l|l|l|l|}
\hline No. & $\begin{array}{l}\text { Fitur Yang } \\
\text { Diujikan }\end{array}$ & $\begin{array}{l}\text { Hasil Yang } \\
\text { Diharapkan }\end{array}$ & Kesesuaian \\
\hline 4. & $\begin{array}{l}\text { Setting } \\
\text { Kategori } \\
\text { Indikator }\end{array}$ & $\begin{array}{l}\text { Pihak } \\
\text { admin } \\
\text { sebagai } \\
\text { pengguna } \\
\text { dapat } \\
\text { mengubah } \\
\text { kategori } \\
\text { indikator }\end{array}$ & $100 \%$ \\
\hline 5. & $\begin{array}{l}\text { Setting } \\
\text { indikator } \\
\text { penilaian }\end{array}$ & $\begin{array}{l}\text { Pihak } \\
\text { admin } \\
\text { sebagai } \\
\text { pengguna } \\
\text { dapat } \\
\text { merubah } \\
\text { indikator } \\
\text { penilaian }\end{array}$ & $100 \%$ \\
\hline
\end{tabular}

Setelah dilakukan pengujian fungsional fitur-fitur yang dihasilkan pada fase iterasi kedua kemudian dilakukan evaluasi untuk mendapatkan feedback atau masukan sehingga dapat meningkatkan kualitas aplikasi SIBOOK Modul Evaluation. Berdasarkan hasil evaluasi yang dilakukan tidak mendapatkan feedback atau masukan dari BPPRD Kota Jambi, sehingga dapat disimpulkan bahwa metode iterative incremental fase kedua sudah memenuhi kebutuhan dan siap untuk diimplementasikan.

Setelah dilakukan tahapan evaluasi kemudian dilanjutkan dengan tahap terakhir yaitu : tahap deployment. Tahap deployment merupakan tahap yang dilakukan setelah fase kedua iterative incremental selesai dilakukan. Tahapan ini dilakukan dengan cara hosting dan domain yang tersedia di BPPRD Kota Jambi. Alat yang digunakan untuk mengunggah ke server menggunakan AnyDesk sebagai remote desktop, virtual server yang sudah disediakan, dan database server yang digunakan yaitu : MySQL. Pada gambar 7 merupakan proses deployment untuk implementasi aplikasi SIBOOK.

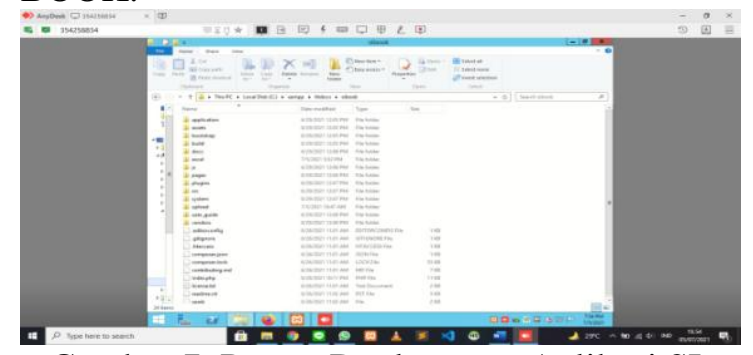

Gambar 7. Proses Deployment Aplikasi SI-

BOOK Pada Virtual Server BPPRD Kota Jambi Dengan AnyDesk

\section{PENUTUP}

Pada penelitian ini dilakukan pengembangan aplikasi website SI-BOOK khususnya untuk Modul Evaluation dengan menggunakan Framework CodeIgniter dan boostrap serta metode pengujian black-box testing sehingga aplikasi dapat diimplementasikan dan dapat digunakan di Badan Pengelola Pajak dan Retribusi Daerah (BPPRD) Kota Jambi dan menujukkan bahwa metode iterative incremental berhasil dilakukan berdasarkan fitur-fitur yang sudah dikembangkan serta untuk pihak BPPRD Kota Jambi dapat memberikan feedback atau masukan selama pengembangan aplikasi SIBOOK yang ada pada Modul Evaluation.

\section{UCAPAN TERIMA KASIH}

Ucapan terima kasih kepada Universitas Telkom dan juga instansi BPPRD Kota Jambi yang telah membantu dalam pelaksanaan penelitian ini.

\section{DAFTAR PUSTAKA}

Ariefni, D. F., \& Legowo, M. B. (2018). Penerapan Konsep Monitoring Dan Evaluasi Dalam Sistem Informasi Kegiatan Mahasiswa Di Perbanan Institute Jakarta. Jurnal Teknik Informatika dan Sistem Informasi, 422.

Hamdala, T., \& Esabella, S. (2020). Rancang Bangun Aplikasi Monitoring dan Evaluasi Penyaluran Dana Sosial Di 
Dinas Sosial Kabupaten Sumbawa Berbasis Web. Jurnal JINTEKS, 106.

Haryana, K. S., 2019. Penerapan Agile Development Methods Dengan Framework Scrum Pada Perancangan Perangkat Lunak Kehadiran Rapat Umum Berbasis QR-CODE. Jurnal Computech \& Bisnis, p. 75.

Hevner, A. R., March, S. T., Park, J. \& Ram, S., 2004. Design Science In Information Systems Research. Mis Quarterly, 28(1).

Iterative Model dalam Software Development. (2020, 07 11). Retrieved from Hemera Academy:https://itlearningcenter.id/ite rative-model-dalam-softwaredevelopment/

J. \& I., 2009. Software Testing Methods and Techniques. The IPSI $\mathrm{BgD}$ Transactions on Internet Research, p. 31.

Moniruzzaman, A. B. M. \& Hossain, S. A., 2013. Comparative Study On Agile Software Development Method. Research Gate, 13(7), p. 6.

Oktaviani, E., Setiawan, H., \& Perdana, K. (2019). Analisa dan Perancangan Aplikasi Manajemen Kinerja CV. Media Kreatif Online. Jurnal Teknologi Informasi Dan Komunikasi.

Raharjana, I. K., 2017. Pengembangan Sistem Informasi Menggunakan Metodologi Agile. Yogyakarta: DEEPUBLISH.

Rahmadi, Y., P, Y. A. \& H, M. A., 2015. Pengembangan Modul Freemium Aplikasi Tel-Us (Telkom University Store) Menggunakan Metode Iterative Incremental dan Framework Laravel. e-Proceeding of Engineering, 2(2), p. 543. 